\title{
Study of Orchids Growing in The Niğde City and Their Habitat Qualities and Threat Factors
}

\author{
Gülden SANDAL ERZURUMLU*1
}

${ }^{1}$ Ömer Halisdemir University, Faculty of Architecture, Department of Landscape Architecture, Nigde, Turkey

Received: 28 April 2017 - Accepted: 03 June 2017

\begin{abstract}
Niğde city is located at the intersection of Iranian-Turanian and Mediterranean phytogeographical areas and is located within B5 and C5 grids according to Davis' (1965) Grid system. This study was carried out in Altınhisar (6 towns, 2 villages), Bor (5 towns, 19 villages), Çamardı ( 2 towns, 18 villages), Çiftlik (4 towns, 9 villages), And Ulukışla (4 towns, 34 villages) within the boundaries of Niğde which is in the specified grids. Niğde and its surroundings are composed of rural areas, having very few forest areas, and due to the destruction caused by various reasons, many plant species are destroyed and face the danger of extinction. One of these plant species is the orchid species. In the research, primarily the types of orchids that have been recorded in the research area within the literature studies have been determined. Orchid species were examined on site, during the field works conducted in March-July 2015-2016. Areas of orchid species were identified in the study and was assessed according to Braun Blanquet cover abundance scale method (1964). In the field studies, various data about the habitat of the species (height, view, sunlight condition, plant species which found together) were collected. Epipactis helleborine, E. Persica, Orchis stevenii, Dactylorhiza saccifera species stated as endemic in Niğde according to TÜBIVES data and E. helleborine have been found in the area of the study. As a result of the field studies in general, orchid species were found only in Çamardı (Pınarbaşı, Çukurbağ, Demirkazık villages) and Ulukışla (Maden Village) districts. Harvesting orchids in the villages of Pınarbaşı and Çukurbağ still continues. As a result of the research, 14 orchid species belonging to the 7 genus which are; Anacamptis laxiflora, Cephalanthera damasonium, Dactylorhiza romana, Epipactis helleborine, E.purpurata, Ophrys Isaura, O. reinholdii, Orchis mascula, O.anatolica, O.purpurea, O. Boryi, O.palustris, ve Serapias vomeracea were determined to live in the area. Morphological information about each species has been given; some suggestions have been made to provide effective protection according to the existing area usage in the habitats. It has been mentioned that harvesting of orchids around Çamard1 still continues and the Directorate of Provincial Food Agriculture and Livestock's work on the orchid cultivation has been mentioned.
\end{abstract}

Keywords: Salep, Niğde, Tübives, Orkide, Toros

\section{INTRODUCTION}

Orchids are a plant family that spread from 0 to 5000 meters altitude in almost every part of the world, from the tropical climate to the temperate climate, which can adapt to all kinds of climate and soil conditions from bogs to rocky fields [4]. The reasons for rich plant diversity and a rich flora in Turkey are, being in an area at the three phytogeographies (Mediterranean, Iranian-Turanian and Siberian), being a bridge between Southern Europe and South-West Asia and Anatolia being the center of origination and differentiation of many species [5]. Turkey is

*Corresponding Author E-mail: gpeyzaj@gmail.com

ISSN: 2148-6905 online /(C) 2017

DOI: $10.21448 / \mathrm{ijsm} .362663$ 
one of the countries with rich floras with about 12,000 ferns and seedy plant taxon. If we consider that the continental flora of Europe has species close to 12,000 and the continent is about 15 times larger than our country, the floristic richness of our country becomes more clear. The interesting part of the Turkish flora arises from the richness of its species, as well as the abundance of endemic species. While the sum of endemic taxa in European countries is about 2750,3925 of the taxa in our country are endemic and endemism rate is around 34\% [9]. Endemic and non-endemic plants grown in Turkey are endangered due to industrialization and urbanization of agricultural areas and the collection of these plants for overgrazing, tourism, export or domestic use, rehabilitation of arid (salt water) areas, uncontrolled and excessive use of agricultural chemicals, pollution and fires. The conservation of plant species is of great importance in the protection of biodiversity, because the destruction of habitats cause the irreversible destruction of species. It is known that there are about 800 orchid genus in the world and around 20000 species under those genus [9]. According to different research results; Papua New Guinea is known to have 3,000 species of Orchidaceae [9]. 1600 in India and 369 in Bhutan which 16 are endemic. In our country there are 268 orchid taxa belonging to 26 genuses. They are named such as dilçıkık, dildamak, çam çiçeği, çobançoluk, tavşan topuğu, katırtırnağ 1 , çayır çiçeği in different regions [4]. Tamer et all. (2006) reported that there are 90 orchid species of 24 genuses used in the production of salep in Turkey [9].

The importance of natural plant sources is increasing day by day. However, because of the overuse of plants that are traditionally used, some plant species are gradually disappearing and the sustainable use of natural resources is being discussed by biologists. For this reason, it is important to investigate many plants that potential have not yet been discovered, both traditionally used and potential, without being destroyed. One of the species that is being destroyed is the salep. The aim of the study is to determine the genus and threat factors of orchid species belonging to the Orchidaceae family present in our country flora [5]. Making a contribution to these kinds of work in our country, to shed light on the new works, and to make the plants consciously used among the people constitute other purposes in this work.

The purpose of this study is; Identifying species of orchids in Niğde and its surroundings together with their habitats, developing the characteristics of the distribution area together with the elements of repression and developing suggestions considering the protection-use balance in the light of all this information.

\section{MATERIAL and METHODS}

\subsection{Material}

The study was carried out in the boundaries of Altunhisar in the west, Çamardı in the east in Niğde region in 2015-2016 (Image 1). The elevation, view, cover status of the area has been determined. Braun Blanquet cover-abundance (1964) method has been used in order to determine the current status of the area. Woody plant taxa and orchid species naturally grown in the area has been exemplified for identifying by sampling and photographing. In plant samples; the orchid plants were taken together with the tubers during the flowering periods and the other plant species were taken to contain the parts that could help the identification of the plants. 


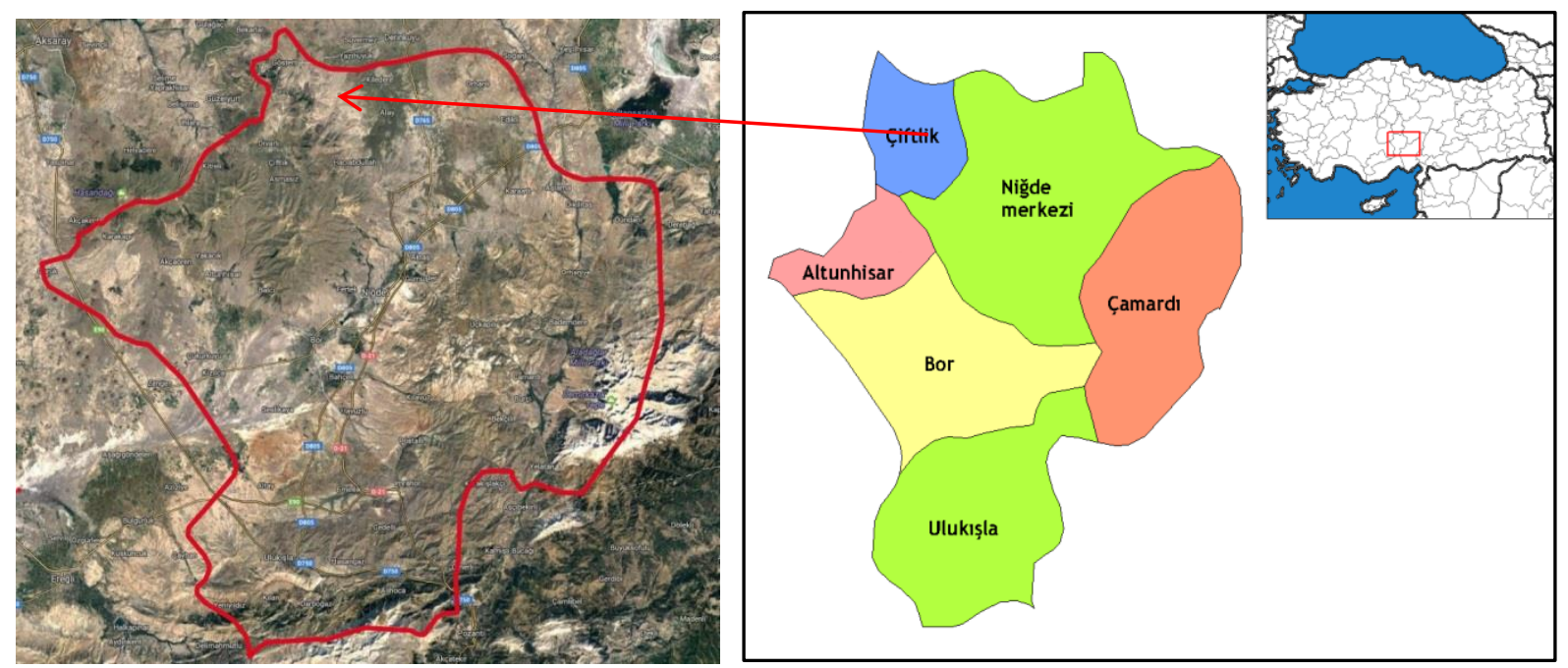

Image 1. Research Area

Butler (1986), Fanfani and Rossi (1988) and Kreutz (1998) were used to identify the orchid species found in the parcels. The distribution of orchid species in Turkey has been determined with the help of Davis' (1984) 8th volume and Ekim et all. (2000). "Türkiye Bitkileri Kırmızı Kitabı, Eğrelti ve Tohumlu Bitkiler" was used for to help with determining the conditions of the species.

Table 1. Locations of Research Parcels

\begin{tabular}{llll}
\hline City & Districts & Villages & Height from sea level \\
\hline \multirow{4}{*}{ Niğde } & Nĭgde & Merkez & 1229 \\
\cline { 2 - 4 } & \multirow{3}{*}{ Çamardı } & Pnarbaşı & 1513 \\
\cline { 3 - 4 } & & Çukurbă & 1550 \\
\cline { 2 - 4 } & Ulukışla & Demirkazık & 1250 \\
\hline
\end{tabular}

In our country, plant belts that have been determined are generally designated as "Upper Mediterranean and Mediterranean Mountain vegetation layers" between 1000-2000 meters. Our research area is located in this belt. 5 areas that contain orchid species were found in the study area.

\subsection{Method}

In the first stage of the research, in order to reveal the characteristics of the growing environment of orchid species in the fields, properties such as altitudes and directions from the sea level were recorded. In addition, the characteristics of orchid species (group or single presence, presence of sunny or shaded area, etc.) were also determined. The Braun Blanquet (1964) method was used to determine the cover status of plant species in the parcels. Woody plant taxa and orchid species naturally grown in the area has been exemplified for identifying by sampling and photographing. In taking plant samples; the orchid plants were taken together with the tubers during the flowering periods and the other plant species were taken to contain the parts that could help the identification of the plants.

Plant samples and woody plant taxa that found in the area has been identified with the help of Altan (2000), Y1lmaz (1996), Matarac1 (2004) and Tekin (2007). Support from Ömer Halisdemir University, Department of Biology, Botanical Science lecturers have been taken. 
The Braun Blanquet (1964) method was used to determine the cover status of the plant species in the parcels (Table 2).

Table 2. Cover-abundance scale

\begin{tabular}{llll}
\hline Scale Value & Cover $(\%)$ & Scale Value & Cover $(\%)$ \\
\hline $\mathrm{r}$ & 1 individual, \%1>cover & $2 \mathrm{~b}$ & $\% 12.5$ to $\% 25$ cover \\
\hline+ & $1-5$ individual, \%1>cover & 3 & $\% 25$ to $\% 50$ cover \\
\hline 1 & $6-50$ individual, \%5>cover & 4 & $\% 50$ to \%75 cover \\
\hline $2 \mathrm{~m}$ & More than 50 individual, \%5>cover & 5 & $\% 75$ to \%100 cover \\
\hline $2 \mathrm{a}$ & $\% 5$ to $\% 12.5$ cover & & \\
\hline
\end{tabular}

\section{RESULTS and DISCUSSIONS}

14 orchid species belonging to 7 genuses were found between 1200-1600 m elevations around Niğde province in submediterranean belt in the research area. Findings obtained from the areas are given below, taking the city borders into consideration. Some of the qualities determined within the borders of Niğde city and the numbers of orchid individuals in the parcels are given in Table 3 .

Table 3. Features of the Research Areas

\begin{tabular}{|c|c|c|c|c|c|}
\hline \multicolumn{2}{|c|}{ Research Area } & Direction & Altitude & Orchid species & Vegetation \\
\hline \multirow[b]{5}{*}{ Niğde } & Merkez & North & 1229 & $\begin{array}{l}\text { O.palustris, } \\
\text { Serapias vomeracea }\end{array}$ & $\begin{array}{l}\text { Malva neglecta } \\
\text { Linum mucronatum }\end{array}$ \\
\hline & $\begin{array}{l}\text { Çamardı } \\
\text { /Pınarbaşı }\end{array}$ & North & 1513 & $\begin{array}{l}\text { Anacamptis laxiflora, } \\
\text { Orchis mascula }\end{array}$ & $\begin{array}{l}\text { Abies cilicica } \\
\text { Cedrus libani }\end{array}$ \\
\hline & $\begin{array}{l}\text { Çamard1 } \\
\text { /Çukurbağ }\end{array}$ & South & 1550 & $\begin{array}{l}\text { Ophrys isaura, } \\
\text { O. reinholdii }\end{array}$ & $\begin{array}{l}\text { Ranunculus demissus } \\
\text { Plantago crassifolia }\end{array}$ \\
\hline & $\begin{array}{l}\text { Çamardı } \\
\text { /Demirkazık }\end{array}$ & South & 1250 & $\begin{array}{l}\text { Dactylorhiza romana } \\
\text { Orchis purpurea, } \\
\text { O. boryi }\end{array}$ & $\begin{array}{l}\text { Isatis glauca } \\
\text { Convolvulus lineatus }\end{array}$ \\
\hline & $\begin{array}{l}\text { Ulukışla/ } \\
\text { Maden }\end{array}$ & North & 1427 & $\begin{array}{l}\text { Cephalanthera } \\
\text { damasonium } \\
\text { Epipactis helleborine, } \\
\text { E.purpurata, } \\
\text { O.anatolica }\end{array}$ & $\begin{array}{l}\text { Alyssum linifolium } \\
\text { Matthiola longipetala } \\
\text { Capparis spinosa }\end{array}$ \\
\hline
\end{tabular}

Following species have been determined in the area; Anacamptis laxiflora, Cephalanthera damasonium, Dactylorhiza romana, Epipactis helleborine, E.purpurata, Ophrys isaura, O. Reinholdii, Orchis mascula, O.anatolica, O.purpurea, O. Boryi, O.palustris, ve Serapias vomeracea.

These orchid species are not found in any category in the "Türkiye Bitkileri Kırmızı Kitab1". Following species have been found together with orchids in the area; Malva neglecta, Linum mucronatum, Abies cilicica, Cedrus libani, Ranunculus demissus, Plantago crassifolia, Isatis glauca, Convolvulus lineatus, Alyssum linifolium, Matthiola longipetala ve Capparis spinosa.

The orchid species in the center of Niğde are being destroyed because of the settlement areas, the salep collecting in Çamard 1 and its surroundings is still continuing and in the Maden village, the orchid species are being destroyed due to agricultural areas. 
Epipactis persica and Orchis stevenii species were not found in the research area that have been determined in the TÜBIVES data. Orchid species found in the research areas are not included in any of the IUCN threat categories.

\section{CONCLUSION}

Due to the fact that Turkey is on the transition belt, it has been the settlement area of various plant species. As in other countries, various protection statutes are inadequate for conservation. Species that need to be protected can be preserved and multiplied when placed in the nature conservation status. On the other hand, species that grow and be in threat in close proximity to the areas can be protected within protected areas.

In recent years, efforts to protect natural life and biodiversity have gained considerable importance in Turkey and in the world. Protection of orchids and especially endangered species is very important. For this purpose, necessary legal arrangements have been made and exports of orchid species and salep in each form are prohibited [9]. Despite any prohibitions on the protection of species, destruction is still ongoing. The work to be done in areas exposed to unauthorized collecting, development in the natural environment, can contribute to the multiplication of orchid individuals. In 2013, similar work has started in the region. Orchid tubers obtained from Aegean Agricultural Research Institute Vegetable Production Development and Alternative Product Project was planted in Çardakık Village in Çamardı District by Niğde Provincial Directorate of Food, Agriculture and Livestock [2]. In Kirklareli forest villages (Y1ld1z Mountains), natural salep farming has started. Since Salep was also accepted as a product outside woody plant in the forest, the General Directorate of Forestry prepared a salep action plan for 2014 - 2018 for the protection of orchid species and for raising public awareness. Besides these, scientific studies have increased as well. Similar activities can be intensified in nature to protect our botanical riches and ecological environments.

\section{Acknowledgement}

Special thanks to my advisor Prof. Dr. Zerrin SÖĞÜT for her help in preparing this paper.

\section{Conflict of Interests}

Authors declare that there is no conflict of interests.

\section{REFERENCES}

[1] Altan, T. (2000). Doğal Bitki Örtüsü. ÇÜ Ziraat Fakültesi Genel Yayın, (235).

[2] Anonim, (2013). http:/www.haberler.com/camard1-na-salep-bitkisi-dikildi

[3] Blanquet, B., \& Pflanzensoziologie, J. (1964). Grudzuge der Vegetationskunde.

[4] Çağlayan, K., Özavcı, A., \& Eskalen, A. (1998). Doğu Akdeniz bölgesinde yaygın olarak yetişen bazı salep orkidelerinin embriyo kültürü kullanılarak in vitro koşullarda çoğaltılmaları. Turkish Journal of Agriculture and Forestry, 22, 187-191.

[5] Çopuroğlu, Ö. (2013). Niğde Yöresindeki Bazı Endemik Bitki Türlerinin Antimikrobiyal Aktiviteleri (Doctoral dissertation, Niğde Üniversitesi).

[6] Davis, P. H. (1965). Flora of Turkey and the east Aegean Islands vols. 1-10. Edinburgh: Edinburgh UniversityPress.

[7] Davis P H (1984) Flora of Turkey and The East Aegean Islands, Vol. 8. Edinburgh University Pres, Edinburgh.

[8] Ekim, T., Koyuncu, M., Vural, M., Duman, H., Aytaç, Z., \& Adıgüzel, N. (2000). Türkiye Bitkileri Kırmızı Kitabı, Eğrelti ve Tohumlu Bitkiler (Red Data Book of Turkish Plants. Pteridophyta and Spermatophyta). Barışçan Ofset. 
[9] Fanfani, A. and Rossi, W. 1988. Simon Schuster s Guide to Orchids. Simon and Schuster Inc., New York, p. 255

[10] Yaman, K. (2013). 1920'den Günümüze TC Resmi Gazete Arşivinde Salep ve Ticareti İle Illgili Yasal Düzenlemeler/Regulations Relating to the Salep and its Trade in Turkish Official Gazette Archives from 1920 to the Present. Journal of History Culture and Art Research, 2(1), 172-180.

[11] Kreutz, C. A. J. (1998). Die Orchideen der Türkei. Beschreibung, Ökologie, Verbreitung, Gefährdung, Schutz. Gorteria, 24(6), 160-160.

[12] Mataracı, T. (2004). Ağaçlar. TEMA Vakfi Yayınları, Yayın, (39), 384.

[13] Tamer CE, Karaman B, Copur OU (2006) A Traditional Turkish beverage: Salep. Food Reviews International 22:43-50.

[14] Tekin, E. (2007). Türkiye' nin en güzel yaban çiçekleri. Türkiye İş Bankası Kültür Yayınları.

[15] Yılmaz, K. T. (1996). Akdeniz Doğal Bitki Örtüsü. ÇÜ Ziraat Fakültesi. Adana 